\title{
The decline of Latin left-peripheral presentational foci: causes and consequences
}

\section{Lieven Danckaert (Ghent University)}

\section{Introduction}

\section{1 'Left Edge Fronting': the phenomenon}

In this paper, I will be concerned with a specific kind of embedded $\mathrm{A}^{\prime}$-movement in Latin whereby one or more constituents are fronted to the left of a conjunction that introduces an embedded clause. The basic pattern is schematically represented in (1), with 'Sub' for 'subordinating conjunction':

\section{(1) $\left[\mathrm{XP}_{\mathrm{i}}\left[\mathrm{Sub} \quad\left[\begin{array}{llll}\mathrm{S} & \ldots & \mathrm{t}_{\mathrm{i}} & \ldots\end{array}\right.\right.\right.$}

I will call this particular linear order 'Left Edge Fronting', LEF for short. In Danckaert (2012), it is argued that Latin LEF comes in two kinds, a topic-like variety LEF1 and a focus-like LEF2 ${ }^{1}$.

In cases of LEF1, the fronted element is always a relative whword (2) or a form of the demonstrative pronouns is or hic (eum 'him, that one' in (3)). In both cases, the fronted element refers to a discourse-old entity, making it plausible to characterize these and other instances of LEF1 as a type of topicalization:

(2) $\left[\right.$ Quod $_{i} \quad[$ cum ti scies $\left.]\right]$, facies ut which-ACC when you-will-know you-will-make that sciamus.

we-know-SUBJ

'When you know this, you will make sure that we know it as well.' (= Cic. ad Att. 8.15.1)

(3) $\left[\operatorname{Eum}_{\mathrm{i}}\left[\right.\right.$ cum ti $\mathrm{i}_{\mathrm{i}}$ uidero]], Arpinum pergam. him-ACC when I-will-have-seen Arpinum-ACC I-will-procede 'When I have seen him, I'll move on to Arpinum.'

(= Cic. ad Att. 9.15.1)

Moreover, LEF1 is only attested in embedded clauses which themselves are located in a leftward position in the clause they are embedded in. In Danckaert (2012: chapters 4 and 5), this left-right asymmetry is analyzed in terms of clausal pied-piping (see also Bayer 2001). The reader is referred to these chapters for further discussion of LEF1, which, despite surface similarities, can be shown to be very different from LEF2, synchronically as well as diachronically. 
On the other hand, the second type of LEF is attested in both clause-initial (4) and clause-final embedded clauses (5).

(4) $\left[\right.$ Antonium $_{\mathrm{i}}\left[\mathrm{si} \mathrm{t}_{\mathrm{i}}\right.$ uidero]], accurate agam Antonius.ACC if I.will.have.seen in.detail I.will.talk de Buthroto. about Buthrotus.ABL

'If I see Antonius, I will inform him in detail about Buthrotus.' (= Cic. ad Att. 14.19.4)

(5) Conloqui uidebamur [[ in Tusculano $]_{i}\left[\right.$ cum $t_{i}$ essem $\left.]\right]$. talk-INF we-seemed-IMPFin Tusculan-ABL when I-was-SUBJ 'It seemed as if we were discussing, when I was in the Tusculan estate.' (= Cic. ad Att. 13.17-18.2)

LEF1 and LEF2 can cooccur in one and the same sentence, as in (6). If so, the LEF1 constituent (quae 'which' in (6)) always precedes the LEF2 phrase (the PP in nouam coloniam 'into the new colony').

(6) [Quae [[in nouam coloniam] [cum introierunt]], which-NOM in new-ACC colony-ACC when have-entered-PF permanent [...] libenter [...]]. they-stay happily 'When they have entered the new colony, they stay there happily.' (= Var. Agr. 3.16.31)

In the present paper, I will only be concerned with this second kind of fronting. In section 2, I will elaborate on the interpretive characteristics of LEF2. After this, I will look at the syntax (section 3) and the diachronic evolution (section 4) of LEF2. First, I will say a couple of words about the 'cartography' of the left periphery of embedded clauses.

\subsection{The position of subordinating conjunctions}

In Rizzi (1997), it is proposed that clause-typing elements are hosted in the highest projection of the split-CP, namely ForceP. For instance, the English complementizer that, which marks the embedded clause as having declarative illocutionary force, is said to be base generated in ForceP. Evidence for this is the observation that the that-complementizer systematically precedes embedded topics and foci (7), witness the ungrammaticality of (8).

(7) John says [ForceP that [TopP [this book] [TP he likes]]].

(8) * John says [this book [that he likes]].

With Roussou (2000), Rizzi (2001) and Krapova (2010), I will assume that clause-typing elements do not systematically coincide with overt subordinating conjunctions. Rather, it 
seems to be the case that a subordinating conjunction can be merged below ForceP. A point in case is Italian se 'if, whether', which can be preceded by a clitic left-dislocated topic:

(9) Non so [Forcep OP [Topp [a Gianni] [IntP se [тP gli ha not I-know to Gianni if him he-has detto la verità]]]]. told the truth

'I don't know if he told Gianni the truth.'

As indicated, I assume that in examples like (9), the embedded clause is typed as an interrogative by a null operator in Spec, ForceP ${ }^{2}$.

Along the same lines, I would to propose that in Latin, subordinating conjunctions like cum 'when' and si 'if' are merged in FinP (see also Krapova (2010: 1257) on the Bulgarian that-complementizer deto). Below, I will argue that LEF2 constituents are hosted in the CP-internal focus projection (section 3.4 ). All this is schematically represented in (10):

(10) [ForceP OP [TopP [FocP LEF2 [FinP Sub [TP ] ] ] ] $]$

In the following section, I will first elaborate on the interpretive characteristics of LEF2. Subsequently, I will present the results of a corpus study, which show that LEF2 is only productive in the earliest stages of the Latin language.

\section{Interpretation and diachrony of LEF2}

\subsection{LEF2 as left peripheral presentational focalization}

\subsubsection{The syntax of presentational foci}

In the literature, it has been proposed that broadly two types of foci should be distinguished (see esp. É. Kiss 1998), which I will call 'identificational' and 'presentational'. According to É. Kiss, the former are operators that obligatorily move to the clausal left periphery, whereas the latter remain in situ and are marked with a pitch accent. Presentational foci are characterized by the same author as non-contrastive, nonquantificational and typically conveying new information.

With Belletti (2001, 2004), I will assume that these apparently in situ presentational foci actually move to a specialized low focus projection at the edge of the $v \mathrm{P}$ phase. I will call this projection FocvP (see also Devine \& Stephens 2006: 28).

Moreover, in recent work, it has been pointed out that in some languages, presentational foci do surface in the CP-domain, without being associated with the expected connotations of 
exhaustivity or contrastivity. Left peripheral presentational foci have been reported for Russian (Bailyn 2003), Sicilian

(Cruschina 2006), Modern Greek (Gryllia 2008), German and

Czech (Fanselow \& Lenertová (2011)).

I will now give a brief overview of the most important characteristics of Latin LEF2.

\subsubsection{On the interpretation of LEF2}

First, in the majority of the cases, an LEF2 constituent conveys non-predictable, brand new information. Consider for instance the sentence in (11). In this example, the city of Capua has not been mentioned before in the letter, and is thus newly introduced into the discourse:

(11) $\left[\right.$ Capuam $_{i}\left[\right.$ cum $_{i}$ uenissem [...]]], consules Capua-ACC when I-had-come-SUBJ consuls-ACC conueni multosque nostri ordinis. I-met-with-PF many-ACC-and our-GEN order-GEN 'When I had come to Capua, I had a meeting with the consuls and many colleagues of the senate.' (= Cic. ad Att. 7.15.2)

Second, LEF2 is freely available in syntactic domains which are cross-linguistically known to disallow so-called 'Main Clause Phenomena', like adverbial clauses (see the examples in $(5-7)$ and (11) $)^{3}$.

Third, there seem to be no restrictions on the category of the phrases that can undergo LEF2. Apart from DPs, we find fronted APs, PPs and even CPs (not illustrated for reasons of space). In general, everything except for inflected verbs and markers of sentential negation can be found to the left of subordinating conjunctions.

Fourth and finally, LEF2 can affect constituents which are clearly not referential or D-linked. A first example is given in (12), in which the nominal element of the idiomatic expression castra mouere 'strike camp (lit. move camp)' has undergone LEF2. In this example, castra clearly is not used to refer to some specific military camp:

(12)Itaque [castra ${ }_{i} \quad\left[\right.$ cum $t_{i}$ mouere uellet]], [... ] PRT camps-ACC when move-INF he-wanted-SUBJ 'And when he then wanted to strike camp,....' (= Anon. Bel. Afr. 6) 
Moreover, bare quantifiers like nihil 'nothing', omnia 'everything' and nemo 'nobody' are attested in an LEF2 position. An example is given in (13):

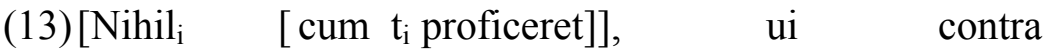
nothing-ACC when he-brought-about-SUBJ force-ABL against uim experiendum putauit. force-ACC to-be-tried-ACC he-thought-PF 'When this brought about nothing, he thought that he should try his luck with brute force.' (= Cic. Phil. 10.23)

The fact that these and other non-referential elements (like nonverbal predicates and secondary predicates) can undergo LEF2, strongly suggests that this phenomenon should not be taken to be a kind of topicalization (Cinque 1986) or scrambling (Diesing 1992): these types of movement typically affect (referential and/or specific) noun phrases.

On the basis of these observations, I would like to propose that LEF2 is a type of presentational (i.e. non-quantificational) focalization.

In section 3, I will develop an analysis that explains how Latin presentational foci end up in the clausal left periphery rather than in the lower FocvP. Before doing so, I will look at the diachronic development of LEF2.

\subsection{Diachronic evolution: decline of LEF2}

In a large-scale corpus study, I have looked at the frequency of LEF2 in adverbial clausesintroduced by the conjunctions cum ('when, because, although'), si 'if' and $u t$ ('so that, in order to,...').

Looking at adverbial clauses has a number of advantages: apart from the fact that these clauses are ubiquitous and easily retrievable in a corpus, they are also adjuncts and by this token strong islands (see Danckaert 2012: 140-142): it follows that we can be reasonably confident that in a sentence like (11) above, the fronted constituent Capuam has not been extracted from the cum-clause to a position in the left periphery of the main clause. Rather, it is moved to the C-domain of the embedded clause.

The texts of the corpus that I have used (see Table x.1) are chronologically organized in five different periods ${ }^{4}$ :

(14)I. Archaic Latin

II. Classical Latin I

III. Classical Latin II

IV. Late Classical Latin I 1st half of the 2 nd century BC

1 st century BC

1 st century AD

1 st half of the 2 nd century $B C$ 
Table x.1 offers an overview of the quantitative data. The figures in the second column show the number of cum-, si- and ut-clauses exhibiting LEF2, compared to the total number of those clauses. The rightmost column shows the relative frequency of LEF2.

Although the limited number of authors per period makes it difficult to make strong diachronic claims (as one cannot exclude that certain tendencies are to be ascribed to stylistic preferences of individual authors rather than to genuine syntactic changes), it seems safe to conclude that LEF2 was mainly productive in the archaic and early classical period. By the end of the first century BC, it started to decline, to become almost completely obsolete in the early second century AD. A modest revival is seen in stage $\mathrm{V}$, probably to be ascribed to imitation of the by then classical models of the (pre-) Augustan era (esp. Plautus, Terentius, Cato and Cicero). ${ }^{5}$

In the remainder of this paper, I will try to better understand this diachronic evolution. A necessary condition for this is of course a proper understanding of the initial and the final synchronich stages.

\subsection{A diachronic hypothesis}

Consider first the minimal pair in (15-16). Both of these little pieces of discourse have essentially the same structure. They consist of two sentences, the first of which contains a lexical item X (underscored), which is literally repeated in a preposed temporal adverbial clause in the second sentence. The basic scheme is twice something like ' ... X ... . And when I say ' $X$ ', I actually mean 'Y".

(15)Mamertini me publice non inuitarunt. Mamertines-NOM me-ACC officially not invited-PF [Me [cum dico]], leue est: [...] me-ACC when I-say light-NOM it-is 'The people of Messana did not officially invite me. And when I say 'me', I consider this a light matter.' (= Cic. Ver. act. sec. 4.25)

(16) Arrianus Maturus Altinatium est princeps. [Cum A-NOM M-NOM Altinates-GEN is chief-NOM when dico princeps], non de facultatibus loquor, [...]. I-say chief-NOM not about means-ABL I-speak 'Arrianus Maturus is the most important man in Altinum. When I say 'most important', I am not referring to his wealth, [...].' (= Pli. Epi. 3.2.2) 
In the example from Cicero (from $70 \mathrm{BC}$ ), the repeated element surfaces in a left peripheral position, i.e. in an LEF2 position. In contrast, in the example from Pliny the Younger (ca. 100 $\mathrm{AD}$ ), the repeated constituent appears postverbally (recall from Table x.1 that LEF2 is (completely) absent in Pliny's work). Given the quasi-identical discourse circumstances of the two examples, I will assume that an LEF2 phrase (15) and the postverbal constituent in (16) are functionally equivalent: both are presentational foci (on postverbal presentational foci, see esp. section 4.2 below).

In the literature, it has been observed that the frequency of INFL-final clauses decreases in the course of the first centuries AD (see Linde 1923; Koll 1965; Bauer 1995), which coincides with the period in which LEF2 became obsolete. In the remainder of this paper, I will pursue the hypothesis that there is a non-trivial correlation between the loss of LEF2 and the increased frequency of non-verb finalword order observed in the history of classical Latin.

In section 3, I will first try to explain how presentational foci could end up in the C-domain (where we do not immediately expect them), and in section 4 I will return to the diachronic evolution.

\section{The derivation of LEF2: $v$ P movement and 'smuggling'}

\subsection{Discourse neutral word order in Latin}

Some introductory remarks are in order. I assume that in each language, there exists a 'discourse neutral' word order, which is typically found in those sentences which can felicitously be uttered as an answer to the question 'what happened?'

Moreover, I will adopt the idea that in each language, the discourse neutral (or 'basic') word order is derived from the universal base by means of (a series of) movement operations (Kayne 1994; Biberauer \& Roberts 2005; Hinterhölzl 2010). Finally, I will assume the Linear Correspondence Axion (Kayne 1994), which says that in the base, specifiers universally precede heads, which universally precede their complements.

There is nowadays some consensus that the discourse neutral word order in Latin was (S)OV(Aux) (see esp. Devine \& Stephens 2006: 79). This basic word order is characterized by two complement-head sequences, namely OV (17-18) and VINFL (18). The latter can only be diagnosed in clauses with an 'analytic' verb form, like secuta est 'has followed' in (18), where the lexical root of the verb and the inflectional morphology are not realized on the same word ${ }^{7}$ : 
(17)Caesar exercitum reduxit.

Caesar-NOM army-ACC led-back-PF

'Caesar led back his army.' (= Caes. Gal. 3.29)

(18) utilitas amicitiam secuta est. utility-NOM friendship-ACC followed-NOM is 'Advantage has followed friendship.' (= Cic. Lael. 51)

For the purposes of the present paper, I will mainly concentrate on the derivation of the second of the two 'head final' orders. Concerning the first, I will just assume that the direct object undergoes 'short movement' to a fairly low position inside the verb phrase (see also Hróarsdóttir 2000; Holmberg 2000; Biberauer \& Roberts 2005 among many others). In the following sections I will propose that that the V-INFL order is derived through movement of a large verbal chunk to a high TP-internal functional projection.

\section{2 vP movement as a way to satisfy the EPP}

It is often assumed that $\mathrm{T}$ is endowed with nominal $(\mathrm{N})$ and verbal (V) features, which need to be 'checked' by syntactic objects with matching nominal and verbal features (see for instance Chomsky 2001: 38) ${ }^{8}$. In the classical case (like in French), T's verbal feature is checked by means of V-to-T movement (with ' $\mathrm{V}$ ' for the complex $\mathrm{V}^{\circ} / v^{\circ}$ ), whereas its nominal feature is checked through movement of the subject DP to Spec,TP. Since Chomsky (1981), the latter movement operation has been understood as being triggered by the EPP ('Extended Projection Principle'), which can loosely be paraphrased as the requirement that every clause have a subject.

From Biberauer \& Roberts $(2005,2006)$ and Biberauer \& Richards (2006), I will adopt the idea that the EPP requirement can be satisfied by movement of a large verbal projection, namely $v \mathrm{P}$. This can be understood as a case of pied-piping: it is actually the subject DP, base generated in Spec, $v \mathrm{P}$ and endowed with the appropriate nominal feature, which is attracted to the middle field. As an accidental by-product, the subject pied-pipes the entire verb phrase, thus giving rise to the surface order V-INFL.

Evidence for the claim that in Latin ${ }^{9}$ it is not a bare subject (typically a DP bearing nominative case morphology) that undergoes A-movement to satisfy the clause's EPP requirement comes from clauses in which a (derived) subject occurs postverbally. Two examples with a passive predicate are given in (19-20), in which the postverbal subject is underscored and the (lexical) verb is marked in boldface ${ }^{10}$.

(19) si non siccentur bacae $[\ldots]$ 
if not are-dried-SUBJ berries-NOM

'if the berries aren't dried.' (= Plin. NH 15.123)
(20) quomodo horum [...] habita ratio est, sic [...] how those-GEN held-NOM respect-NOM is so 'like respect has been paid to them, so ... .' (=Sen. Ben. 3.11.1)

\section{3 vP movement in Latin}

We are now in a position to explain how Latin sentences exhibiting the discourse neutral word order SOV(Aux) (as in (17-18) above) are derived from the Universal Base. First of all, I will assume that auxiliaries are base generated in some functional head in the split TP, say $\mathrm{T}^{\circ}$. On the other hand, I will assume that synthetic verb forms undergo V-to-T movement: given the rich agreement morphology of Latin finite verbs, this seems not an unlikely hypothesis. Second, along the lines of the discussion in the previous section, I assume that the entire $v \mathrm{P}$ moves to a position to the left of $\mathrm{T}^{\circ}$ : this verbal category then contains (i) the verb's arguments and (ii) the lexical verb or its trace $^{11}$. As outlined in the previous section, I assume that the trigger for this movement operation is the EPP feature with which, by assumption, each clause is endowed.

There is reason to believe that the target of $\nu \mathrm{P}$ is not the specifier of the tense phrase, the head of which is occupied by the finite verb. Evidence for assuming a relatively high target position for the moved verb phrase comes from examples like (21), in which the direct object (i.c. a CP) and the lexical verb passus 'permitted, allowed' are separated from the clause-final auxiliary sum 'I am' by the negator non 'not':

\section{(21) $\left[\right.$ meas ruinas] $\left[\mathrm{CP}\right.$ quarum ${ }_{\mathrm{i}}$ ego $\left[_{\mathrm{FP}}\left[{ }_{\mathrm{vP}}\left[\mathrm{CP}\right.\right.\right.$ similem $t_{\mathrm{i}}$ my-ACC ruins-ACC which-GEN I-NOM similar-ACC totam urbem esse] passus $]_{j}$ non $t_{j}$ sum] [...]. whole-ACC city-ACC be-INF permitted-NOM not I-am (lit.) 'my destruction, similar to which I did not allow the entire city to be.' (= Cic. De domo sua 124)}

Therefore, I propose that the nominal and the verbal features of the T-domain are not located on the same functional projection $^{12}$ : rather, they are associated with two different functional heads, which are separated by at least one other functional head, namely NegP. I will not try to be very specific about the identity of the head endowed with the EPP-feature: I will just call it FP, for 'Functional Projection'. Perhaps this projection is to be equated to the dedicated subject position 'SubjP' proposed in Cardinaletti (2004) (see also Rizzi 2006), which is also situated a high position in the split-TP. 
The derivation of a Latin clause with a synthetic verb form would then look like (22), with movement of the $v^{\circ} / \mathrm{V}^{\circ}$ complex to $\mathrm{T}^{\circ}$, and movement of the remnant $v \mathrm{P}$ to Spec,FP.

(22) $\left[\mathrm{FP}\left[{ }_{v P} \mathrm{DP}_{\mathrm{S}} \mathrm{DP}_{\mathrm{O}} \mathrm{t}\right]\left[\mathrm{F}^{\circ}[\mathrm{EPP}]\left[\mathrm{NegP}\left[\mathrm{TP}\left[\mathrm{T}^{\circ} \mathrm{V}_{\mathrm{j}}\left[\mathrm{FocvP}_{\mathrm{P}} \mathrm{t}_{\mathrm{vP}}\right]\right]\right]\right]\right]\right]$

Crucially, the landing site of $v \mathrm{P}$ is not only higher than negation, but also higher than the lower focus phrase Foc $v \mathrm{P}^{13}$. In the following section, I will explain why this is relevant.

\subsection{Smuggling: a way to avoid intervention}

The basic idea is that a presentational focus moves to the CPinternal focus position because it is itself contained in a larger category which by default moves to a position higher than the lower focus projection. This is more formally stated in (23):

(23) In Latin, a presentational focus XP moves to FocP iff XP is dominated by YP and YP c-commands FocvP.

In our Latin case, YP in (23) stands for the A-moved $v \mathrm{P}$. If the analysis developed above is on the right track, this would amount to a 'smuggling' derivation, whereby the large verbal projection, containing $\mathrm{XP}$, moves past Foc $v \mathrm{P}$, thus avoiding an intervention effect that would arise if XP were to move on its own.

The mechanism of smuggling as a way to avoid a minimality violation is defined by Collins (2005a: 97) as follows ${ }^{14}$ :

Suppose a constituent YP contains XP. Furthermore, suppose that XP is inaccessible to $\mathrm{Z}$ because of the presence of $\mathrm{W}$ (a barrier, phase barrier, or an intervener for the Minimal Link Condition and/or Relativized Minimality), which blocks a syntactic relation between $\mathrm{Z}$ and XP (e.g. movement, Case checking, agreement, binding). If YP moves to a position c-commanding $\mathrm{W}$, we say that YP smuggles XP past W.

The 'smuggling' derivation of an LEF2 configuration would be as in (24a). I assume that since an independent step in the derivation has made Foc $v \mathrm{P}$ unavailable for a constituent to move into, the left peripheral FocP becomes the closest potential Probe for a presentational focus. As a host for presentational foci, the left peripheral FocP is so to speak only a 'second best'.

(24)a. [ForceP [FocP $\mathrm{XP}_{\mathrm{i}}\left[\right.$ FinP $\operatorname{Sub}\left[\mathrm{FP}\left[{ }_{\nu \mathrm{P}} \mathrm{t}_{\mathrm{i}} \mathrm{t}_{\mathrm{j}}\right]\left[\mathrm{T}^{\circ} \mathrm{V}_{\mathrm{j}}\left[\right.\right.\right.$ FocvP $\left.\left.\left.\left.\left.\left.\mathrm{t}_{\nu \mathrm{P}}\right]\right]\right]\right]\right]\right]$ 
Crucially, $v \mathrm{P}$ movement is a precondition for LEF2. The ungrammatical derivations (24b-c) show that the presentational focus XP cannot reach the higher FocP by its own force, whether it moves 'in one fell swoop' (24b) or with an intermediate movement step to a functional projection in the middle field, say AgrOP (24c) $)^{15}$.

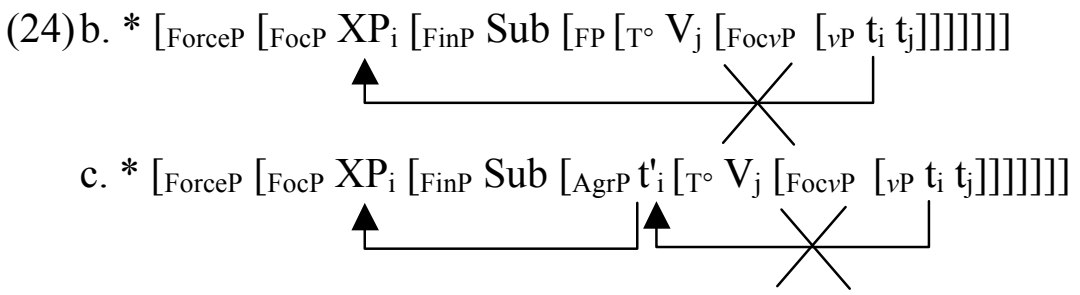

Consider for instance the example in (25a), in which a direct object has been moved to the left periphery of a conditional clause. The schematic derivation of this example is given in (25b).

(25)a. [ Antoni-umi $\left[\right.$ si ti $_{\mathrm{i}}$ uidero]], [...].

Antonius-ACC if I-will-have-seen

'If I see Antonius,... .' (= Cic. ad Att. 14.19.4)

b. [ForceP $\left[\right.$ FocP Antonium ${ }_{i}\left[\right.$ FinP $\operatorname{si}\left[\mathrm{FP}\left[\nu \mathrm{P} \mathrm{t}_{\mathrm{i}} \mathrm{t}_{\mathrm{j}}\right]\left[\mathrm{T}^{\circ}\right.\right.$ uidero $_{\mathrm{j}}\left[\mathrm{FFocvP}_{\mathrm{P}}[\right.$ $\mathrm{t}_{v \mathrm{P}}$ ]]]]]]]

Before turning to the diachronic analysis, two remarks are in order. First, the non-quantificational nature of presentational foci (É. Kiss 1998) allows LEF2 constituents to appear in the left periphery of clauses that generally do not allow for 'Main Clause Phenomena', like adverbial clauses (see section 2.1.2 above). I refer to Haegeman $(2009,2010 a, b)$ for an explicit proposal as to why quantificational operators are disallowed in the left periphery of most adverbial clauses.

Second, it should be noted that the present proposal is not compatible with a strictly derivational approach to information structure, as e.g. in López (2009). One could assume that 'peripheral' discourse-related movement operations take place later than core syntactic operations as A-movement (cf. Zubizarreta 1998: 29-33), so as to avoid that a $v$ P-internal phrase with a focus feature moves to Foc $v \mathrm{P}$ as soon as the latter is merged, but I acknowledge that this is a potential problem.

In the remainder of this paper, I will concentrate on the diachronic development of LEF2. As hinted at in section 2.3, I will propose that the loss of LEF2 goes hand in hand with an increased frequency of postverbal presentational foci, and thus with an increased frequency of non INFL-final clauses. 


\section{The loss of $v P$ movement and its consequences}

\subsection{Reanalysis of $v \mathbf{P}$ movement}

I would like to propose that the decline of LEF2 is to be ascribed to the loss of its conditio sine qua non, namely $v \mathrm{P}$ movement. Following Biberauer \& Roberts (2005: 25), who discuss a very similar directionality shift that took place during the transition from Old to Middle English, I suppose that movement of a large verbal projection $(v \mathrm{P})$ was reanalyzed by the language acquirer as a series of independent movement operations of the verb and its arguments (as was proposed in Zwart (1993) for the OV-order of Dutch). Consider the derivations in (26):

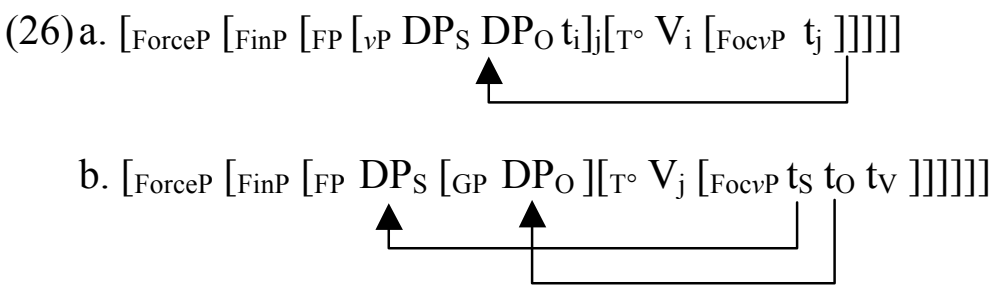

In (26a), we see the by now familiar derivation that can give rise to LEF2: $v \mathrm{P}$ is pied-piped when the subject DP is attracted to Spec,FP. On the other hand, in (26b), the subject moves on its own to the designated subject position, stranding the verb phrase, and the direct object moves to a position in the middle field, possible a case position (like AgrOP). The crucial observation is that although both derivations yield the same linear output, their underlying structure is fundamentally different.

It should be noted that in the second derivation, the trigger for subject movement, namely the EPP requirement, is arguably stronger than the trigger for object movement. Actually, it is not entirely clear whether the object moves to check a(n abstract) case or agreement feature, or some definiteness feature. In any event, we predict that it is not unlikely that in a grammar without obligatory $v \mathrm{P}$ movement, object movement does not take place systematically. As I will show in the final part of the paper, this is indeed the case.

\subsection{Postverbal presentational foci}

Latin never was a strictly INFL-final language: the order $\mathrm{V}_{\text {fin }}$ $\mathrm{XP}$ is attested from the earliest records onwards. However, there is an interesting diachronic development concerning the nature of the constituents that could appear in a clause-final position, which seems to support the analysis developed in the present $\operatorname{paper}^{16}$. 
As pointed out in Devine \& Stephens (2006: 119-123), in authors whose syntax was predominantly INFL-final (like Caesar), the majority of postverbal constituent are PPs, as in (27):

(27)Exercitum reducit [Pp ad mare]. army-ACC leads-back to sea-ACC 'He led the army back to the sea.' (= Caes. Gal. 5.23)

Assuming that an argumental PP like the directional expression ad mare 'to the sea' in (27) is merged in some low position in TP (see Schweikert 2005: 123-129), the present account correctly predicts that it can be appear postverbally. As shown in (28), we only have to assume that the base position of the PP, here labelled 'DirP' for 'Directional Phrase' is not included in the category that undergoes A-movement.

(28) $\left[\mathrm{FP}\left[{ }_{\nu P}\right.\right.$ exercitum $\left._{\mathrm{k}} \mathrm{t}_{\mathrm{j}} \mathrm{t}_{\mathrm{k}}\right]\left[\mathrm{TP}\right.$ reducit $_{\mathrm{j}}\left[\mathrm{DirP}[\mathrm{PP}\right.$ ad mare $\left.\left.\left.] \mathrm{t}_{v \mathrm{P}}\right]\right]\right]$.

In a later stage, the possibility for direct objects to appear to the right of the inflected verb becomes productive as well: arguably, this is the stage in which $v \mathrm{P}$ movement is (gradually) lost. The postverbal objects typically come with a special pragmatic flavour: they are either destressed 'tail' constituents (in the sense of Vallduví 1992) or they are presentational foci. For reasons of space, I will only briefly discuss the latter.

According to Devine \& Stephens (2006: 128-129), the first type of direct object that appears as a postverbal presentational focus is a non-referential indefinite DP, often denoting an abstract concept, like fugam 'flight' in (29) ${ }^{17}$ :

(29)plerique [...] capessunt fugam. most-NOM-and take flight-ACC

'the majority fled away.' (= Liv. aUc 33.9.11)

This is exactly the type of DP that is a likely candidate to not undergo movement to the middle field: it is well known that indefinite nouns tend to stay inside the verb phrase, whereas definite or D-linked nouns are typically moved out of it (see esp. Diesing 1992; cf. also Bobaljik \& Thráinsson (1998: 54) on the status of object DPs that undergo object shift in Icelandic).

Postverbal direct objects are generalized only much later. However, we could assume that the increased frequency of postverbal direct objects has been a considerable factor in the eventual shift from an OV- to a VO-grammar. 


\section{Conclusion}

In this paper, I have looked at the syntax and the diachronic evolution of a particular strategy of left peripheral focalization, which I referred to as LEF2. I have characterized LEF2 constituents as presentational foci, and I have argued that their left peripheral position is parasitic on $v \mathrm{P}$ movement to the middle field. I suggested that the loss of this $v \mathrm{P}$ movement lies at the basis of the loss of LEF2.

In future research, it would be interesting to widen the empirical domain by looking at main clauses as well. However, it would presumably be very difficult to diagnose this phenomenon in non-embedded environments, as in most main clauses, the linear string provides us with no clues as to where the boundary between $\mathrm{CP}$ (the left periphery) and TP (the core clausal domain) is located: therefore, an LEF2 constituent in many cases would be indistinguishable from for instance an XP scrambled to the high TP. The only possibility would be to look at matrix constituent questions (given that XPs can occur to the left of question words). However, assuming that wh-phrases in matrix questions are hosted in FocP (see Rizzi 1997), it is not certain whether a landing site for an LEF2 constituent would be available.

\section{References}

Alexiadou, Artemis \& Elena Anagnostopoulou. 1998. Parametrizing AGR: word order, movement and EPPchecking, NLLT 16, 491-539

Bailyn, John. 2003. Does Russian scrambling exist? In S. Karimi (ed.). Word order and scrambling. Malden (Mass.): Blackwell, 156-176

Bauer, Brigitte. 1995. The emergence and development of SVO patterning in Latin and French. Oxford: O.U.P.

Bayer, Josef. 2001. Asymmetry in emphatic topicalization. In C. Féry \& W. Sternefeld (eds.), Audiatur vox sapientiae: a Festschrift for Arnim von Stechow. Berlin: Akademie Verlag, 15-47

Belletti, Adriana . 2001. 'Inversion' as focalization. In A. Hulk \& J.-Y. Pollock (eds.). Subject inversion in Romance and the theory of universal grammar. Oxford: O.U.P., 60-90

Belletti, Adriana. 2004. Aspects of the low IP area. In L. Rizzi (ed.). The structure of CP and IP. Oxford: O.U.P., 16-51

Belletti, Adriana \& Luigi Rizzi. 2012. Moving verbal chunks in the low functional field. In L. Brugé, A. Cardinaletti, G. Giusti, N. Munaro \& C. Poletto (eds.). Functional heads. Oxford: O.U.P., 129-137

Biberauer, Theresa \& Ian Roberts. 2005. Changing EPP parameters in the history of English: accounting for variation and change, ELaL 9, 5-46 
Biberauer, Theresa \& Ian Roberts. 2006. Loss of residual 'head final' orders and remnant fronting in Late Middle English: causes and consequences. In J. Hartmann \& L. Molnárfi (eds.). Comparative studies in Germanic syntax. Amsterdam: Benjamins, 263-297

Biberauer, Theresa \& Marc Richards. 2006. True optionality: when the grammar doesn't mind. In C. Boeckx (ed.). Minimalist essays. Amsterdam: Benjamins, 35-67

Biberauer, Theresa, Anders Holmberg \& Ian Roberts. To appear. A syntactic universal and its consequences, $L I$

Bobaljik, Jonathan \& Höskuldur Thráinsson. 1998. Two heads aren't always better than one, Syntax 1, 37-71

Cardinaletti, Anna. 2004. Towards a cartography of subject positions. In L. Rizzi (ed.). The structure of CP and IP. Oxford: O.U.P., 115-165

Chomsky, Noam. 1981. Lectures on government and binding. Dordrecht: Foris

Chomsky, Noam. 2001. Derivation by phase. In M. Kenstowicz (ed.). Ken Hale: a life in language. Cambridge (Mass.): MIT Press, 1-52

Cinque, Guglielmo. 1986. Bare quantifiers, quantified NPs and the notion of operator at S-structure, $R G G 11,33-63$

Cinque, Guglielmo. 1999. Adverbs and functional heads: across-linguistic perspective. Oxford: O.U.P.

Collins, Chris. 2005a. A smuggling approach to raising in English, LI 36, 289-298

Collins, Chris. 2005b. A smuggling approach to the passive in English, Syntax 8, 81-120

Conte, Gian Biagio. 1994. Latin literature: a history (translated by Joseph B. Solodow, revised by Don Fowler \& Glenn W. Most). Baltimore: The John Hopkins University Press

Cruschina, Silvio. 2006. Informational focus in Sicilian and the left periphery. In M. Frascarelli (ed.). Phases of interpretation. Berlin: Mouton de Gruyter, 363-385

Danckaert, Lieven. 2012. Latin embedded clauses: the left periphery. Amsterdam: Benjamins

Devine, Andrew \& Laurence Stephens. 2006. Latin word order: structured meaning and information. Oxford: O.U.P.

Diesing, Molly. 1992. Indefinites. Cambridge (Mass.): MIT Press

É. Kiss, Katalin. 1998. Identificational focus versus information focus, Language 74, 245-273

Embick, David. 2000. Features, syntax and categories in the Latin perfect, $L I 31,185-230$

Fanselow, Gisbert \& Denisa Lenertová. 2011. Left peripheral focus: mismatches between syntax and information structure, NLLT 29, 169-209 
Gryllia, Stella. 2008. On the nature of preverbal focus in Greek: a theoretical and experimental approach. Ph.D. diss. University of Leiden

Haegeman, Liliane. 2000. Remnant movement and OV order. In P. Svenonius (ed.), The derivation of $O V$ and $V O$. Amsterdam: Benjamins, 69-96

Haegeman, Liliane. 2009. Operator movement and topicalisation in adverbial clauses, ELaL 13, 385-408

Haegeman, Liliane. 2010a. The internal syntax of adverbial clauses, Lingua 120, 628-648

Haegeman, Liliane. 2010b. The movement derivation of conditionals, $L I 41$, 595-621

Hinterhölzl, Roland. 2010. Information structure and unmarked word order in (Older) Germanic. In M. Zimmermann \& C. Féry (eds.). Information structure: theoretical, typological and experimental perspectives. Oxford: O.U.P., 282-303

Hooper, Joan \& Sandra Thompson. 1973. On the applicability of root transformations, $L I$ 4, 465-497

Hróarsdóttir, Porbjörg. 2000. Word order change in Icelandic: from $O V$ to $V O$. Amsterdam: Benjamins

Hróarsdóttir, Porbjörg. 2010. Information structure and OV order. In M. Zimmermann \& C. Féry (eds.). Information structure: theoretical, typological, and experimental perspectives. Oxford: O.U.P., 258-281

Kayne, Richard. 1994. The antisymmetry of syntax. Cambridge (Mass.): MIT Press

Kenney, Edward \& Wendell Clausen (eds.). 1982. The Cambridge history of classical literature II: Latin literature. Cambridge: C.U.P.

Koll, Hans-Georg. 1965. Zur Stellung des Verbs im spätantiken und frühmittelalterlichen Latein, Mittellateinisches Jahrbuch 2, 241-272

Koopman, Hilda \& Anna Szabolcsi. 2000. Verbal complexes. Cambridge (Mass.): MIT Press

Krapova, Iliyana. 2010. Bulgarian relative and factive clauses with an invariant complementizer, Lingua 120, 1240-1272

Linde, Paul. 1923. Die Stellung des Verbs in der lateinischen Prosa, Glotta 12, 153-178

López, Luis. 2009. A derivational syntax for information structure. Oxford: O.U.P.

Mahajan, Anoop. 2003. Word order and (remnant) VP movement. In S. Karimi (ed.). Word order and scrambling. Malden (Mass.): Blackwell, 217-237

Pearson, Matthew. 2000.Two types of VO languages. In P. Svenonius (ed.), The derivation of $O V$ and $V O$. Amsterdam: Benjamins, 327-363

Rizzi, Luigi. 1997. The fine structure of the left periphery. In L. Haegeman (ed.). Elements of grammar. Dordrecht: Kluwer, 281-337 
Rizzi, Luigi. 2001. On the position Int(errogative) in the left periphery of the clause. In G. Cinque \& G. Salvi (eds.). Current studies in Italian syntax: essays offered to Lorenzo Renzi. Amsterdam: Elsevier, 287-296

Rizzi, Luigi. 2006. On the form of chains: criterial positions and ECP effects. In L. Cheng \& N. Corver (eds.). Whmovement: moving on. Cambridge (Mass.): MIT Press, 97133

Roussou, Anna. 2000. On the left periphery: modal particles and complementizers, JGL 1, 65-94

Schweikert, Walter. 2005. The order of prepositional phrases in the structure of the clause. Amsterdam: Benjamins

Shlonsky, Ur. 2010. The cartographic enterprise in syntax, Language and Linguistics Compass 4, 417-429

Vallduví, Enric. 1992. The informational component. New York: Garland

Zubizarreta, Maria-Luisa. 1998. Prosody, focus and word order. Cambridge (Mass.): MIT Press

Zwart, Jan-Wouter. 1993. Dutch syntax: a minimalist approach. Ph.D. diss. University of Groningen 


\begin{tabular}{|c|c|c|c|}
\hline & \multicolumn{3}{|c|}{ Table x.1: Diachronic evolution of LEF2 } \\
\hline & \multirow[t]{2}{*}{ Author, work (date) } & \multicolumn{2}{|c|}{ Frequency of LEF2 } \\
\hline & & $\mathbf{n}=$ & $\%$ \\
\hline I & Cato, De agricultura (160 BC) & $49 / 372$ & $13,2 \%$ \\
\hline \multirow[t]{6}{*}{ II } & Cicero, Ad Atticum (68-43 BC) & $76 / 2337$ & $3,3 \%$ \\
\hline & Anon. I, Bellum Afr. (ca. 40 BC) & $11 / 141$ & $7,8 \%$ \\
\hline & Anon. II, Bellum Hisp. (ca. 40 BC) & $11 / 125$ & $8,8 \%$ \\
\hline & Anon. III, Bellum Alex. (ca. 40 BC) & $5 / 163$ & $3,1 \%$ \\
\hline & Varro, Res rustica (36 BC) & $88 / 783$ & $11,2 \%$ \\
\hline & Vitruvius, De architectura (ca. 20 BC) & $99 / 1293$ & $7,7 \%$ \\
\hline \multirow[t]{2}{*}{ III } & Velleius Pat., Historiae (30 AD) & $2 / 304$ & $0,7 \%$ \\
\hline & Columella, De agricultura (40-50 AD) & $29 / 2289$ & $1,3 \%$ \\
\hline \multirow[t]{3}{*}{ IV } & Frontinus, Aq. + Strat. (ca.90 AD) & $5 / 522$ & $1,0 \%$ \\
\hline & Plinius, Epist. + Paneg. (90-110 AD) & $0 / 1302$ & $0 \%$ \\
\hline & Tacitus, Ann. + Hist. (100-110 AD) & $15 / 1281$ & $1,2 \%$ \\
\hline \multirow[t]{4}{*}{$\mathrm{V}$} & Fronto, Epistulae (150-170 AD) & $10 / 384$ & $2,6 \%$ \\
\hline & Gaius, Institutiones (ca. 170 AD) & $13 / 1161$ & $1,1 \%$ \\
\hline & Apuleius, Flor. + Mag. (170-180 AD) & $13 / 453$ & $2,9 \%$ \\
\hline & Total: & $426 / 12910$ & \\
\hline
\end{tabular}

\footnotetext{
${ }^{1}$ For more detailed discussion, the reader is referred to Danckaert (2012: ch. 3 ), where it is shown among other things that LEF is also attested in other old languages (like Vedic Sanskrit and Ancient Greek), as well as in a number of modern languages (as Modern Greek and Bulgarian).

${ }^{2}$ On the clause typing operator in adverbial clauses, see Haegeman (2009, 2010a,b).

${ }^{3}$ See Hooper \& Thompson (1973) and Haegeman (2009, 2010a,b).

${ }^{4}$ This subdivision into five periods is to some extent motivated by time gaps between two texts in my corpus. Note that data from the early Latin period are unfortunately scarce: Cato's de Agricultura is the only extant prose text. ${ }^{5}$ In the philological literature, the style of Fronto and Apuleius is generally considered to be 'archaizing'. Thus F. Goodyear (in Kenney \& Clausen (eds.) 1982: 677) on Fronto: '[...] he certainly tried to exploit anew the latent resources of Latin literature, by going back beyond the stylists of the early Empire, and beyond Cicero and his contemporaries, to extract from the archaic writers whatever he might effectively use.' Similarly, Conte (1994: 581): 'The limits and variations of the archaizing tendency are neatly symbolized by its triumphant leader, Marcus Cornelius Fronto.' More or less the same can be said about Apuleius; Conte (1994: 567): 'Living in a period of enthusiasm for the archaic, Apuleius naturally shares the fondness of his contemporaries for obsolete words [...] and for archaic authors [...].' The relatively high frequences of LEF2 in this authors can therefore be interpreted as an (indirect) indication that this phenomenon was a feature of the earlier stages of the Latin language. Finally, it comes as no surprise that Gaius, the third author of the fifth period, uses LEF2 less frequently than his two more literary contemporaries: this author wrote a technical treatise on law and did not do any attempt to imitate or emulate the style and language of earlier models.

${ }^{6}$ I refer to Schweikert (2005: 54-86) for extensive discussion of ways to establish which is the 'basic' word order in a given language.
} 
${ }^{7}$ Observe that despite the passive morphology and the be-auxiliary, a predicate like sequor 'I follow' (perfect tense secutus sum 'I followed') is genuinely transitive (cf. the accusative marked direct object amicitiam 'friendship' in (18) (see also Embick 2000).

${ }^{8}$ See Alexiadou \& Anagnostopoulou (1998) for a slightly different view.

${ }^{9}$ that is to say, at least in the earliest stages of the language (see section 4).

${ }^{10}$ On examples like (20), exhibiting the order '(passive) past participlesubject-auxiliary', see Biberauer, Holmberg \& Roberts (to appear: 12, fn. 5). I will have nothing to say about the peculiarities of this particular word order pattern: I have chosenthis example because it shows a postverbal subject which is clearly not extraposed or right-dislocated.

${ }^{11}$ see also Haegeman (2000); Koopman \& Szabolcsi (2000); Pearson (2000); Hróarsdóttir (2000, 2010); Mahajan (2003); Biberauer \& Roberts (2005, 2006); Biberauer \& Richards (2006), among others.

${ }^{12}$ This complies with a very common assumption in the cartographic tradition, which says that each there is a one-to-one relation between syntactic features and functional heads (see for instance Shlonsky 2010).

${ }^{13}$ A possible example where a postverbal presentational focus, (which, as we will see in section 4.2 , becomes only available in a fairly late stadium of the Latin language), is found lower than sentential negation is given in (ia). I assume that this example can be represented as in (ib).

(i) a. Myron [...] non inuenit heredem. Myron.NOM not found.PF heir.ACC

'Myron [...], did not find a heir.' (= Petr. Sat. 88)

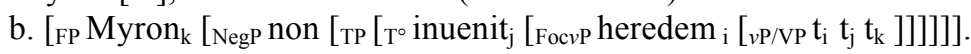

${ }^{14}$ A note of caution is in order: I assume that 'smuggling' does not exist as a primitive operation. I consider the avoidance of an intervention effect to be an accidental by-product of two (or possibly more) independently motivated operations.

${ }^{15}$ For some more case studies of derivations in which the operation of 'smuggling' plays a role, see Cinque (1999: 21-28), Collins (2005a,b); Belletti (2004: 36); Belletti \& Rizzi (2012).

${ }^{16}$ The upcoming discussion will be based on Devine \& Stephens (2006). See also Danckaert (2012: 327-333).

${ }^{17}$ Other examples with an abstract noun as a postverbal presentational focus include facit amicitiam 'he makes friendship' (Nep. Dat. 14.5.6) and derigebant cursum 'they directed their course' (Liv. aUc 37.27.1). 